\title{
Samoprocjena promjena ponašanja učenika osnovnih škola s problemima u ponašanju nakon sudjelovanja u socijalnopedagoškim intervencijama
}

\author{
Meliha Bijedić \\ izvanredna profesorica na Odsjeku za poremećaje u ponašanju \\ Edukacijsko - rehabilitacijski fakultet Univerziteta u Tuzli \\ $\square$ E-mail:meliha.bijedic@untz.ba \\ Lejla Kuralić Čišić \\ docentica na Odsjeku za poremećaje u ponašanju \\ Edukacijsko - rehabilitacijski fakultet Univerziteta u Tuzli
}

Adela Jahić

viša asistentica na Odsjeku za poremećaje u ponašanju Edukacijsko - rehabilitacijski fakultet Univerziteta u Tuzli

Melisa Muminović Vildić

asistentica na Odsjeku za poremećaje u ponašanju Edukacijsko - rehabilitacijski fakultet Univerziteta u Tuzli

\begin{abstract}
Sažetak
Cilj rada bio je prikazati rezultate Programa socijalnopedagoških intervencija za učenike koji su u rizičnoj skupini razvijanja problema u ponašanju. Program se provodio u trima osnovnim školama na području grada Tuzle u Bosni i Hercegovini, a realiziran je tijekom 2016./2017. školske godine. Provedena je procjena 500 učenika (248 dječaka i 252 djevojčice) u dobi od 10 do 15 godina, od čega je izdvojeno 86 učenika (39 dječaka i 47 djevojčica) kod kojih je procijenjeno da su u rizičnoj skupini za razvoj problema u ponašanju. Za procjenu je korištena Achenbachova dimenzionalna klasifikacija poremećaja ponašanja (Achenbach, Rescorla, 2001), a da bi se utvrdili efekti Programa, učenici su testirani u inicijalnoj, medijalnoj i finalnoj fazi. Strukturiranim pedagoškim postupcima putem skupnoga i individualnog pristupa došlo je do promjene u ponašanju učenika prema društveno poželjnim modelima. Skupni i individualni susreti s učenicima realizirani su u trajanju od dva sata tjedno, a Programom su putem radionica educirani nastavnici i roditelji. Da bi se prikazale promjene kod učenika s eksternaliziranim i internaliziranim problemima, korištene su deskriptivne statističke metode na Youth Self Report skalama. Programom je potvrđeno očekivanje da će, pravovremenom identifikacijom učenika rizičnih za nastanak problema u ponašanju i pravovremenom i adekvatnom socijalnopedagoškom intervencijom u radu s djecom i njihovim roditeljima, doći do pozitivnih pomaka u ponašanju.
\end{abstract}

Ključne riječi: problemi u ponašanju, učenici osnovne škole, samoprocjena, socijalnopedagoške intervencije 


\section{Uvod}

Škole su jedno od najvažnijih okruženja za provođenje adekvatnih i pravovremenih intervencijskih programa budući da imaju središnju ulogu u poticanju akademskoga, ali i socijalnoemocionalnog razvoja učenika. Obveznim školskim programom obuhvaćena su sva djeca te su u školskom okruženju najveće mogućnosti široke prevencije, rane detekcije, identifikacije i intervencije, što uključuje pravodobno uočavanje djeteta koje odrasta u rizičnim okolnostima. Školska okruženja sama po sebi nisu izravni činitelji poremećaja i poteškoća, ali najčešće su prva mjesta na kojima se poteškoće manifestiraju u ozbiljnim razmjerima (Bouillet i Uzelac, 2007). Zajednički cilj procjene rizika i potreba djece i mladih pronalaženje je intervencija u skladu s utvrđenim potrebama. Intervencija se definira kao bilo koja mjera ili društvena aktivnost poduzeta na kontinuumu djelovanja od prepoznavanja do mijenjanja jednog ili više činitelja rizika za pojavu problema u ponašanju (Žižak, 2010). U užem smislu socijalnopedagoška intervencija podrazumijeva skup stručnih aktivnosti usmjerenih prema sprečavanju ili ublaživanju socijalnih problema učenika, djelujući u smjeru poticanja pozitivnih promjena u ponašanju i uvjetima u kojima učenici odrastaju i razvijaju se (Bouillet, 2016). Učenici s problemima u ponašanju imaju potrebu za socijalnopedagoškom intervencijom koja obuhvaća sve važne aspekte njihova života, osobito obiteljske odnose, probleme vezane za školovanje i odnose s vršnjacima. U tom smislu socijalnopedagoška intervencija usmjerena je prema ublaživanju utjecaja nepovoljnih socijalnih uvjeta koji umanjuju mogućnost primjerena razvoja, školskog uspjeha i socijalne integracije učenika (Barnett, 2011., prema Bouillet, Bićanić, Ivančan i sur., 2018). U provedenom Programu, koji je opisan u radu, to su najčešće adekvatne i pravovremene rane intervencije koje su realizirane kod djece koja su u rizičnoj skupini za nastanak problema u ponašanju. Intervencije su bile usmjerene na pravovremeno prepoznavanje problema i zaustavljanje njegova širenja u najranijoj fazi razvoja problema u ponašanju.

Ovakve pravovremene intervencije na kontinuumu intervencija uvrštene su na razinu selektivne prevencije. Europski centar za droge i ovisnosti (European Monitoring Centre for Drugs and Drug Addiction, 2009, prema Pavin Ivanec, 2015) ranu intervenciju na kontinuumu prevencije poremećaja u ponašanju smjestio je u razinu selektivne prevencije kojoj prethodi univerzalna prevencija, a na koju se nadovezuje indicirana razina prevencije. Radi se o intervenciji usmjerenoj selekcioniranim učenicima koji se uključuju u univerzalne i ranointerventne školske kurikule i aktivnosti, dok učenici s intenzivnim problemima u ponašanju traže/zahtijevaju intervencije i tretmane, koji u pravilu nadilaze mogućnosti same škole i podrazumijevaju interdisciplinaran i međuresorski pristup u zajedničkom djelovanju različitih služba lokalne zajednice.

Žižak (2010) uz pojam rane intervencije za djecu i mlade s problemima u ponašanju vezuje njihovu potrebu za pojačanom skrbi, zaštitom, pomoći, nadzorom i vođenjem. Osnovna svrha takve podrške zaustavljanje je mogućega nepovoljna razvoja djece i umanjivanje mogućnosti da problemi postanu trajni i/ili teško rješivi, najčešće putem jačanja zaštitnih čimbenika u okruženju u kojemu dijete živi i razvija se, ali i osiguravanjem dugoročnijih oblika i sadržaja stručne podrške djeci i njihovim obiteljima. Rana odgojno-obrazovna intervencija ciljano je stručno i sveobuhvatno, poglavito pedagoško, djelovanje u školskom okruženju prema učenicima koji su iz različitih razloga izloženi riziku razvoja problema u ponašanju (Bouillet, 2015). 
Svjetska literatura upućuje na podatak da najmanje jedno od petero (dakle, 20\%) djece i mladih pati od nekog oblika i razine problema u ponašanju dok njih $10 \%$ ima ozbiljne teškoće u socijalnom funkcioniranju (Boydell Brauner i Bowers Stephans, 2006, prema Bouillet, 2015).

Planiranje svake intervencije i različitih programa podrške učenicima, školi i roditeljima trebalo bi započeti procjenom trenutnog stanja.

Pastor, Reuber i Duran (2012) na reprezentativnom uzorku djece u dobi od četiri do sedamnaest godina za SAD ustvrdili su da probleme u ponašanju prema Upitniku sposobnosti i teškoća učenika ima 7\% djece. Abu-Rayya i Yang (2012) zaključuju da je u Australiji u riziku razvoja ozbiljnih problema u ponašanju 7,6\% djece mlađe od 15 godina. Ipak, podatci o prevalenciji problema u ponašanju djece osnovnoškolske dobi razlikuju se od studije do studije i kreću se u rasponu od 3,5\% do 32,3\%, ovisno o kriterijima procjena (Conley, Marchant i Caldarella, 2014), pri čemu učitelji izvještavaju prosječno o tri učenika s problemima u ponašanju u svakom razredu (Conroy i Brown, 2004, prema Bouillet, 2016). U uzorku učenika mlađe školske dobi koji manifestiraju probleme u ponašanju, na uzorku 921 učenika iz šest hrvatskih osnovnih škola, Pavin Ivanec (2015) ustvrdila je da određene probleme u ponašanju (uključujući rizična ponašanja) manifestira $20 \%$ učenika u dobi od 7 do 10 godina.

Praksa temeljena na pokazateljima uspješnosti podrazumijeva korištenje provjerenih vještina, tehnika i strategija u izravnu kontaktu stručnjaka i korisnika, što dovodi do razvoja dokazano učinkovitih programa u formi organiziranih, slojevitih, multidisciplinarnih intervencija usmjerenih prema osobama sa složenim problemima (Bouillet, 2015). Učenici sa složenim problemima su oni koji su zbog niza čimbenika, poput socioekonomskih i obiteljskih prilika, akademskog uspjeha, odnosa s vršnjacima... u riziku za nastanak problema u ponašanju. Ukratko, radi se o planiranju praktičnog rada temeljem poznatih empirijskih spoznaja koje osiguravaju postizanje željenih ishoda. Kada je riječ o socijalnopedagoškim intervencijama, praksa temeljena na dokazima uspješnosti dobrim dijelom ovisi o potrebama samih učenika, odnosno o teškoćama za koje je socijalni pedagog, u suradnji sa samim učenikom, procijenio da najviše ometaju njegovo uravnoteženo socijalno funkcioniranje u školi. Smisao procjene potreba učenika s problemima u ponašanju je u njezinoj kvaliteti i primjerenosti intervencijskih potreba koje bi trebale dovesti do smanjivanja ili ublaživanja problema, odnosno do pozitivnih promjena koje svakoj osobi omogućavaju optimalnu uključenost u svakodnevni život u zajednici (Koller-Trbović, Mirosavljević, Jeđud Borić, 2013).

\section{Problem, cilj i hipoteza istraživanja}

Učenici u riziku za nastanak problema u ponašanju imaju potrebu za adekvatnom i pravovremenom socijalnopedagoškom intervencijom koja će obuhvatiti sve važne aspekte njihova života, posebno obiteljske odnose, probleme vezane uz školovanje (uspjeh i poštovanje pravila) i odnose s vršnjacima. U tom smislu, adekvatna socijalnopedagoška intervencija usmjerena je na ublaživanje utjecaja nepovoljnih uvjeta koji umanjuju mogućnost primjerena razvoja, školskog uspjeha i socijalne integracije rizične skupine učenika. Radi se o intervenciji usmjerenoj prema učenicima, a provodi se u školskim okruženjima. 
Svrha je istraživanja prikazati rezultate samoprocjene promjena ponašanja učenika osnovnih škola s problemima u ponašanju nakon sudjelovanja u socijalnopedagoškim intervencijama.

U istraživanju se počelo s pretpostavkom da će kod svih učenika, uključenih u intervencijski program, doći do pozitivnih promjena u ponašanju.

\section{Metodologija istraživanja}

\section{Sudionici}

Istraživanje je provedeno na uzorku od 500 učenika (248 dječaka i 252 djevojčice) od petog do devetog razreda osnovne škole, od čega je primjenom Achenbachove (Achenbach, Rescorla, 2001) Youth Self-Report ljestvice izdvojeno 86 učenika (39 dječaka i 47 djevojčica) kod kojih je procijenjeno da su u riziku za pojavu problema u ponašanju. Od ukupnog broja učenika koji su u riziku za pojavu problema u ponašanju, roditeljska suglasnost dobivena je za 38 učenika, koji su potom uključeni u socijalnopedagoški tretman u trima osnovnim školama na području grada Tuzle u Bosni i Hercegovini. Istraživanje i provođenje intervencija trajalo je od rujna do lipnja 2016./2017. školske godine. Svi učenici (38) nisu istovremeno uključeni u Program jer su roditeljske suglasnosti za uključenje jedne trećine učenika dobivene naknadno. To znači da je jedna skupina od 12 učenika pridružena u intervencijski program nakon šezdeset dana od njegova početka.

\section{Instrument}

U ovom istraživanju korišten je instrument Youth Self Report Scale (Achenbach, Rescorla 2001). Radi se o samoiskazu koji ima uvodni dio i ljestvicu te česticama dotiče sve značajne aspekte funkcioniranja djeteta u odnosu na njegovo najuže okruženje, obitelj, ali i odnose s vršnjacima, kao i s odraslim važnim osobama u školi i okruženju. Ovim instrumentom moguće je mjeriti adaptivno funkcioniranje, odnosno kompetencije i maladaptivno funkcioniranje, odnosno bihevioralne, emocionalne i socijalne probleme. Instrument sadrži osam skala specifičnih sindroma koje mjere probleme s tendencijom udružena pojavljivanja, a to su: anksioznost - depresivnost; povučenost; somatske tegobe; socijalni problemi; problemi mišljenja; problemi pažnje; ponašanje kojim se krše pravila i agresivno ponašanje. Sindromi su grupirani u eksternalizirane i internalizirane. Eksternalizirani sindromi odnose se na konflikte s drugim ljudima i njihovim očekivanjima i tu se ubraja ponašanje kojim se krše pravila i agresivno ponašanje (primjeri tvrdnji: „kršim pravila kod kuće, u školi i dr.", "često zadirkujem druge"). Internalizirani sindromi odnose se na psihološke poteškoće usmjerene na pojedinca i pretjerano kontrolirana ponašanja, a tu se ubrajaju: anksioznost/depresivnost, povučenost, somatske tegobe (primjeri tvrdnji: „povučen sam", ", nastojim se držati po strani", "nesretan sam, tužan ili potišten"). Ponašanje se procjenjuje na 112 tvrdnji na trostupanjskoj ljestvici. Zadatak učenika je da na svaku od tih 112 tvrdnji u upitniku odgovore: 0 - nije točno, 1 - povremeno točno ili 2 - često točno. Viši rezultati podrazumijevaju zamjetniju zastupljenost rizika za nastanak problema u ponašanju; rezultati viši od 70 na sindromskim ljestvicama klinički su značajni jer ukazuju na visoku razinu problema. Mjerni instrument preuzet je od autorice Kuralić-Čišić (2013), koja je prevela i standardizirala skalu na domaćoj populaciji. Pouzdanost YSR skale ocijenjena je primjenom 
Cronbach alfa koeficijenta. Vrijednost ovog koeficijenta za cjelokupnu YSR skalu iznosi 0,93 što označava visoku razinu pouzdanosti, odnosno internu konzistenciju ovog instrumenta.

\section{Način prikupljanja podataka i provođenja intervencija}

Podatci su prikupljeni na način da su učenici samostalno popunjavali upitnik, tj. samoprocjenjivali su vlastito ponašanje i funkcioniranje, izražavajući samoprocjenu na trostupanjskoj ljestvici (netočno, povremeno točno, često točno). Samoprocjena učenika obavljala se u trima fazama. Inicijalna procjena obavljena je na početku školske godine te je nakon tri mjeseca primijenjenih intervencija i efektivnog rada učinjena ponovna samoprocjena učenika koji su bili marljivo uključeni u kontinuirane aktivnosti. Nakon završetka Programa (na kraju školske godine) učinjena je završna samoprocjena učenika da bi se provjerila uspješnost intervencija.

Pravovremene i adekvatne socijalnopedagoške intervencije, čiji se rezultati žele prikazati, primijenjene su tijekom cijele školske godine radom u malim skupinama (podijeljenim po razredima), a prema potrebi $\mathrm{i}$ individualnim sastancima s pojedinim učenicima. Skupni sastanci održavani su jedanput tjedno poslije redovitih nastavnih aktivnosti ili nakon njih u trajanju od dva sata. Sadržaj rada bio je visoko strukturiran i usmjeren na edukaciju i trening socijalnih vještina, jačanje motivacije za akademska postignuća te razvijanje odnosa u skladu s vršnjačkim. Posebna se pozornost usmjerila procijenjenim rizičnim čimbenicima na koje se djelovalo ciljanim intervencijama u odnosu na procijenjene potrebe. Osim s učenicima, tijekom školske godine realizirana su po tri predavanja i radionice za roditelje i nastavnike.

Formiranje učeničkih skupina prvi je korak u realizaciji primjerenih intervencija. Skupine su formirane prema učeničkoj dobi, a daljnji rad određivao se prema tematskim cjelinama radionica, ciljeva i načina rada, mjesta i vremena odvijanja skupnog rada, izbora metoda i tehnika koje se primjenjuju u radu. Ciljevi rada skupine u Programu podijeljeni su na sljedeći način: 1. Ciljevi postavljeni za svaku pojedinu skupinu; 2 . Individualni ciljevi za svakog učenika iz skupine.

Prema unaprijed izrađenu okvirnome izvedbenom planu s podijeljenim planiranim sadržajima tijekom školske godine, formirani su ciljevi koji se ostvaruju kontinuirano. U tom planu ugrađeni su konkretni ciljevi rada prema obrazovnim razdobljima učenika, a koji su određeni prema potrebama skupine i pojedinaca. Uglavnom, odnose se na postizanje takvih promjena koje će djeci omogućiti uspješnije funkcioniranje u odnosu prema sebi, prema drugima i prema okolini. Ti ciljevi proizlaze iz osnovnih ciljeva Programa, a neki od specifičnih ciljeva rada skupine su: usmjeravanje članova skupine na aktivno sudjelovanje u radu, stvaranje okruženja za razvoj skupnih procesa; upoznavanje i povezivanje skupine, stvaranje identiteta skupine, stvaranje i osnaživanje kohezije, razvoj skupne dinamike, proces rastanka, razvoj interakcije skupine i pojedinca: poticanje na uočavanje i razumijevanje značenja pripadnosti skupini i rezultata koji se stimuliraju radom u skupini, uočavanje međusobnih razlika i sličnosti i razvijanje svijesti o tome, razvoj kvalitetnije komunikacije unutar skupine, učenje zadovoljavanja osobnih potreba unutar zajednice bez sukoba, upozoravanje na potrebu prihvaćanja pravila i normi društva uz poštovanje vlastite individualnosti, učenje odgovarajućih oblika ponašanja u konfliktnim situacijama, tolerancije i suradnje te nošenje s problemima i sa stresnim situacijama. 
Problemi u ponašanju, kao i potrebe učenika koji se uključuju u Program, nisu tretirani samo u kontekstu skupnog rada jer kod nekih učenika može postojati potreba za pojačanim radom, a za pojedine je učenike možda potrebno organizirati rad samo individualnim pristupom. Za učenike kod kojih pristup putem skupnih metoda nije optimalan, ponekad zbog nedostatka socijalnih vještina unutar skupine pa čak i izbjegavanja sudjelovanja u bilo kakvim skupinama, može biti jedan od oblika manifestiranja djetetovih problema. Svi učenici, koji su od početka uključeni u intervencije, prošli su između 30 i 36 skupnih susreta tijekom školske godine. Učenici koji su naknadno uključeni u Program prošli su između 17 i 20 skupnih susreta tijekom trajanja intervencija.

Učenike za individualni rad odabirali su voditelji prema svojoj slobodnoj procjeni, uočivši njihove probleme koje je potrebno tretirati takvim oblikom rada. Individualno je rađeno s 26 učenika. Svi učenici, koji su uključeni u individualni rad, imali su između 15 i 25 individualnih susreta. Voditelji radionica i individualnih intervencija bili su socijalni pedagozi.

Individualni rad sa svakim učenikom specifična je situacija u odnosu na procijenjene rizične čimbenike te o načinima na koje će se provoditi odlučuju isključivo voditelji temeljem svojih akademskih i stručnih kompetencija, znanja, iskustava, prikupljenih podataka, intuicije i u dogovoru sa svim sudionicima uključenima u Program. Za svakog učenika s kojim se planira individualni rad, pripremljen je plan i program rada. Neki od ciljeva individualnog rada s učenicima su: razvijanje pozitivne slike o sebi i svojim mogućnostima, razvijanje pozitivne slike o drugima, razvijanje osjećaja odgovornosti za svoje postupke i ponašanja, prepoznavanje vlastitih sposobnosti, interesa, želja i izbora, razmišljanje o sebi kao onome tko bira i donosi odluke, snalaženje u svakodnevnim situacijama i reagiranje na što odgovorniji način, kao i razvijanje sposobnosti snalaženja u novim situacijama, sposobnosti komunikacije s vršnjacima, nastavnicima i roditeljima, prepoznavanje djetetove uloge u obitelji, upozoravanje na obiteljske vrijednosti i njihovu važnost, razvijanje socijalnih vještina, razvijanje kreativnosti, razvijanje samostalnosti, samopouzdanja i veće neovisnosti u skladu s dobi. 
Meliha Bijedić, Lejla Kuralić Čišić, Adela Jahić, Melisa Muminović Vildić: Samoprocjena...

\section{Metode obrade podataka}

U istraživanju su korištene deskriptivne statističke metode.

\section{Rezultati i rasprava}

Ispitanici s kojima su provedene socijalnopedagoške intervencije testirani su na početku (što je i bio temeljni kriterij za uključenje), zatim nakon određena perioda utjecaja intervencijskih aktivnosti (u središnjoj fazi) te u završnoj fazi, uzimajući u obzir da s jednim brojem ispitanika nisu provođene socijalnopedagoške intervencije odmah na početku školske godine, kad nije bilo svrsishodno raditi središnju procjenu, te je kod tih učenika izvršena procjena kada se počelo intervenirati i nakon svršetka školske godine, a time i tretmana, što je prikazano u tablici 1.

Tablica 1. Obuhvaćenost ispitanika u odnosu na razvoj sindroma

\begin{tabular}{|c|c|c|c|c|c|}
\hline \multirow[b]{2}{*}{ Internalizirani i eksternalizirani } & \multirow{2}{*}{$\begin{array}{c}\begin{array}{c}\text { I } \\
\text { samoiskaz }\end{array} \\
3\end{array}$} & \multirow{2}{*}{$\begin{array}{c}\begin{array}{c}\text { II } \\
\text { samoiskaz }\end{array} \\
3\end{array}$} & \multirow{2}{*}{$\begin{array}{c}\begin{array}{c}\text { III } \\
\text { samoiskaz }\end{array} \\
3\end{array}$} & \multicolumn{2}{|c|}{$\begin{array}{c}\text { Obuhvaćenost učenika fazama } \\
\text { testiranja }\end{array}$} \\
\hline & & & & $100,0 \%$ & $100,0 \%$ \\
\hline Internalizirani & 9 & 5 & 9 & $55,6 \%$ & $100,0 \%$ \\
\hline Internalizirani i problemi pažnje & 7 & 7 & 7 & $100,0 \%$ & $100,0 \%$ \\
\hline Problemi pažnje & 4 & 4 & 4 & $100,0 \%$ & $100,0 \%$ \\
\hline Eksternalizirani problemi, problemi pažnje & 4 & 3 & 4 & $75,0 \%$ & $100,0 \%$ \\
\hline Eksternalizirani & 11 & 2 & 11 & $18,2 \%$ & $100,0 \%$ \\
\hline Broj ispitanika & 38 & 24 & 38 & $63,2 \%$ & $100,0 \%$ \\
\hline Maksimum & 146 & 99 & 67 & & \\
\hline Minimum & 49 & 20 & 0 & & \\
\hline
\end{tabular}

Iz tablice 1 može se uočiti da su svi ispitanici kategorizirani u odnosu na neki od osam sindroma, koji su bili iznad kliničkog ranga 70, na koji su procijenjeni. Dvije trećine učenika (više od 60,0\%) procijenjeni su u trima fazama (inicijalnoj, središnjoj i završnoj). Drugim testiranjem obuhvaćeno je ukupno 24 ispitanika, odnosno (63,2\%), dok su trećim testiranjem bili obuhvaćeni svi. U nastavku rada bit će prikazana uspješnost intervencija za svaki sindrom iz tablice 1 ostvarenim rezultatima u početnom, središnjem i završnom samoiskazu.

Tablica 2. Uspješnost intervencija kod ispitanika s rizikom za razvoj kombiniranih internaliziranih $i$ eksternaliziranih problema

\begin{tabular}{|l|c|c|c|c|c|c|c|}
\hline \multirow{2}{*}{ Statističke vrijednosti } & $\begin{array}{c}\text { Redni broj } \\
\text { ispitanika }\end{array}$ & $\begin{array}{c}\text { Ukupan } \\
\text { rezultat na I } \\
\text { samoiskazu }\end{array}$ & $\begin{array}{c}\text { Ukupan } \\
\text { rezultat na II } \\
\text { samoiskazu }\end{array}$ & $\begin{array}{c}\text { Ukupan } \\
\text { rezultat na III } \\
\text { samoiskazu }\end{array}$ & \multicolumn{2}{|c|}{$\begin{array}{c}\text { Uspješnost intervencija izražena u } \\
\text { postotcima }\end{array}$} \\
\cline { 2 - 8 } & 1. & 2 & 3 & 4 & $5(3 / 2)$ & $6(4 / 3)$ & $7(4 / 2)$ \\
\cline { 2 - 8 } & 2. & 122 & 53 & 29 & $43,8 \%$ & $35,6 \%$ & $63,8 \%$ \\
\cline { 2 - 8 } & 3. & 71 & 47 & 62 & $36,6 \%$ & $0,0 \%$ & $56,6 \%$ \\
\hline Broj ispitanika & & 3 & 3 & 3 & & & \\
\hline Maksimum & & 122 & 53 & 62 & $56,6 \%$ & $35,6 \%$ & $63,8 \%$ \\
\hline Minimum & & 71 & 45 & 29 & $33,8 \%$ & $-31,9 \%$ & $12,7 \%$ \\
\hline
\end{tabular}

U tablici 2 vidljivo je da su tri ispitanika, uključena u socijalnopedagoške intervencije, izražavala kombinirano eksternalizirane i internalizirane probleme. Kod ispitanika pod rednim brojem 1. uočen je primjetan pozitivan utjecaj već u središnjoj fazi procjene $(35,6 \%)$ te nakon završetka aktivnosti 
u odnosu na inicijalnu procjenu zabilježen je značajan rezultat pozitivne promjene u ponašanju (63,8\%). Za ispitanika pod rednim brojem 2. došlo je do napretka već nakon određenog vremena za 56,0\%, ali se taj rezultat zadržao do kraja. Kod trećeg ispitanika na središnjoj samoprocjeni došlo je do negativna rezultata što je posljedica obiteljskih prilika u kojima se učenik našao u središnjoj fazi samoprocjene. Riječ je o učeniku koji je promijenio hraniteljsku obitelj te je prolazio proces adaptacije na novu sredinu življenja. Do kraja intervencijskog djelovanja i kod učenika pod rednim brojem 3. došlo je do pozitivna ishoda.

Problemi u ponašanju često se javljaju zajedno s drugim poremećajima. Epidemiološke studije otkrivaju da oko $70 \%$ djece i mladih s jednim od izraženih oblika poremećaja ponašanja, uzrasta od sedam do trinaest godina, ispunjava kriterije za postavljenje još jedne dijagnoze (Kazdin, 1993, prema Žunić-Pavlović, Kovačević-Lepojević 2010). Tako su poremećaji pažnje povezani s poremećajima ponašanja, pogotovo ako se javljaju u komorbiditetu s ADHD-om. MacDonald i Achenbach (1999, prema Liabo, Richardson, 2007), ustvrdili su da komorbiditet poremećaja u ponašanju s ADHD-om dovodi do problema u ponašanju u školi, zlouporabe psihoaktivnih supstancija, češćih kontakata sa službama mentalnog zdravlja i većom učestalosti suicidalna ponašanja nego kada se javi samo jedan od ovih problema.

U kliničkim i epidemiološkim istraživanjima, pojam «komorbiditet» često se koristi za opisivanje pojave postojanja dvaju ili više različitih problema ili sindroma kod iste osobe (Achenbach, Dumenci, i Rescorla, 2003), međutim, smatra se da je izraz komorbiditet primjenjiv samo za dijagnosticirane bolesti. Budući da eksternalizirani i internalizirani problemi nisu dijagnoze, preporučuje se korištenje izraza povezanost ili kovarijacija nekoliko tipova problema ponašanja kod djeteta. Zbog svega navedenoga, smatralo se značajnim prikazati ovu skupinu ispitanika odvojeno od internaliziranih te pokazati u kojoj je mjeri Program utjecao na njih (tablica 3).

Tablica 3. Uspješnost intervencija kod ispitanika s rizikom za razvoj internaliziranih problema $i$ problema pažnje

\begin{tabular}{|c|c|c|c|c|c|c|c|}
\hline \multirow[t]{2}{*}{ Statističke vrijednosti } & \multirow[t]{2}{*}{$\begin{array}{l}\text { Redni broj } \\
\text { ispitanika }\end{array}$} & \multirow{2}{*}{$\begin{array}{c}\begin{array}{c}\text { Ukupan } \\
\text { rezultat na I } \\
\text { samoiskazu }\end{array} \\
2\end{array}$} & \multirow{2}{*}{$\begin{array}{c}\begin{array}{c}\text { Ukupan } \\
\text { rezultat na II } \\
\text { samoiskazu }\end{array} \\
3\end{array}$} & \multirow{2}{*}{$\begin{array}{c}\begin{array}{c}\text { Ukupan } \\
\text { rezultat na III } \\
\text { samoiskazu }\end{array} \\
4\end{array}$} & \multicolumn{3}{|c|}{$\begin{array}{l}\text { Uspješnost intervencija izražena u } \\
\text { postotcima }\end{array}$} \\
\hline & & & & & $5(3 / 2)$ & $6(4 / 3)$ & $7(4 / 2)$ \\
\hline & 1. & 77 & 69 & 25 & $10,4 \%$ & $63,8 \%$ & $67,5 \%$ \\
\hline & 2. & 91 & 67 & 60 & $26,4 \%$ & $10,4 \%$ & $34,1 \%$ \\
\hline & 3. & 70 & 36 & 15 & $48,6 \%$ & $58,3 \%$ & $78,6 \%$ \\
\hline & $4 .$. & 79 & 29 & 10 & $63,3 \%$ & $65,5 \%$ & $87,3 \%$ \\
\hline & 5. & 72 & 41 & 53 & $43,1 \%$ & $-29,3 \%$ & $26,4 \%$ \\
\hline & 6. & 78 & 44 & 63 & $43,6 \%$ & $-43,2 \%$ & $19,2 \%$ \\
\hline & 7. & 70 & 99 & 48 & $-41,4 \%$ & $51,5 \%$ & $31,4 \%$ \\
\hline Broj ispitanika & & 7 & 7 & 7 & & & \\
\hline Maksimum & & 91 & 99 & 63 & $63,3 \%$ & $65,5 \%$ & $87,3 \%$ \\
\hline Minimum & & 70 & 29 & 10 & $-41,4 \%$ & $-43,2 \%$ & $19,2 \%$ \\
\hline
\end{tabular}

Svi ispitanici s internaliziranim problemima i s problemima pažnje testirani su u trima fazama procjene. Ispitanici iz ove skupine problema iznimno su osjetljivi na pravovremene socijalnopedagoške intervencije, s pokazateljima uspješnosti do $87,3 \%$. Najmanji je pomak od $19,2 \%$ u ispitanika pod rednim brojem 6 . Budući da nije bilo pomaka na središnjoj samoprocjeni, učenik pod rednim brojem 
6., osim skupnih radionica, uključen je i u individualni rad sa socijalnim pedagogom. S obzirom na specifičnosti rizičnih čimbenika, utvrđenih tijekom individualnih susreta, potrebno je produžiti provedbu intervencija.

Deficit pažnje (ADD) najčešća je dijagnoza koju dobivaju djeca školskog uzrasta, čak 7 - 10\% djece uzrasta od 5 do 18 godina ima dijagnozu ADD-a. Poremećaji pažnje češće se javljaju kod dječaka (odnos je od $6: 1$ do $10: 1$ ). Ti problemi u 70\% slučajeva ne nestaju s odrastanjem (Gadow, Nolan, Litcher i sur., 2000). Studije pokazuju i to da su, bez adekvatna tretmana, djeca s problemima pažnje u daleko većem riziku od neuspjeha u školi ili uspjeha ispod njihovih intelektualnih sposobnosti, kao i da je 20 - 30\% takve djece imalo sukobe sa zakonom te da nakon punoljetnosti imaju daleko veći broj (4 puta više od onih bez deficita pažnje) prometnih prekršaja u kojima je netko povrijeđen; također, učestalost razvoda u obiteljima u kojima djeca imaju deficit pažnje dvostruko je veća, a veća je i sklonost takve djece prema bolestima ovisnosti (Jackson, 2005). Djecu s deficitom pažnje nastavnici i sredina u kojoj žive često doživljavaju kao lijenu, drsku, neodgojenu i nemirnu, što u velikoj mjeri utječe na njihovo samopoštovanje i stvaranje negativne slike o sebi (Barkley i sur., 2002). U uzorku našeg istraživanja, na YSR ljestvici izdvojila su se četiri ispitanika sa sindromske ljestvice s Problemima pažnje (tablica 4).

Tablica 4. Uspješnost intervencija kod ispitanika s problemima pažnje

\begin{tabular}{|c|c|c|c|c|c|c|c|}
\hline \multirow[t]{6}{*}{ Statističke vrijednosti } & \multirow[t]{2}{*}{$\begin{array}{l}\text { Redni broj } \\
\text { ispitanika }\end{array}$} & \multirow{2}{*}{$\begin{array}{c}\begin{array}{c}\text { Ukupan } \\
\text { rezultat na I } \\
\text { samoiskazu }\end{array} \\
2\end{array}$} & \multirow{2}{*}{$\begin{array}{c}\begin{array}{c}\text { Ukupan } \\
\text { rezultat na II } \\
\text { samoiskazu }\end{array} \\
3\end{array}$} & \multirow{2}{*}{$\begin{array}{c}\begin{array}{c}\text { Ukupan } \\
\text { rezultat na III } \\
\text { samoiskazu }\end{array} \\
4\end{array}$} & \multicolumn{3}{|c|}{$\begin{array}{c}\text { Uspješnost intervencija izražena } \\
\text { postotcima }\end{array}$} \\
\hline & & & & & $5(3 / 2)$ & $6(4 / 3)$ & $7(4 / 2)$ \\
\hline & 1. & 82 & 36 & 19 & $56,1 \%$ & $47,2 \%$ & $76,8 \%$ \\
\hline & 2. & 99 & 59 & 42 & $40,4 \%$ & $28,8 \%$ & $57,6 \%$ \\
\hline & 3. & 146 & 43 & 33 & $70,5 \%$ & $23,3 \%$ & $77,4 \%$ \\
\hline & 4. & 77 & 25 & 5 & $67,5 \%$ & $80,0 \%$ & $93,5 \%$ \\
\hline Broj ispitanika & & 4 & 4 & 4 & & & \\
\hline Maksimum & & 146 & 59 & 42 & $70,5 \%$ & $80,0 \%$ & $93,5 \%$ \\
\hline Minimum & & 77 & 25 & 5 & $40,4 \%$ & $23,3 \%$ & $57,6 \%$ \\
\hline
\end{tabular}

Pokazatelji uspješnosti intervencija u završnoj procjeni ove skupine ispitanika su 50,0 - 90,0\%. Pokazatelji uspješnosti bili su kontinuirani tijekom obiju faza testiranja. Intervencijski pristupi, koji se koriste kod djece s problemima pažnje, dok se još nisu razvili pravi simptomi, pedagoško-edukacijski i bihevioralno-kognitivni su da bi se kontrolirali simptomi i ublažili specifični problemi djeteta. Ti intervencijski pristupi primijenjeni su u skupnom radu s djecom uključenom u Program u setovima radionica koje su imale za cilj postizanje takvih promjena koje će djeci omogućiti uspješnije funkcioniranje u odnosu na sebe, na druge i na okolinu. S obzirom na to da se svi simptomi i popratne poteškoće ne javljaju kod sve djece, a različita je i njihova etiologija, primjenjuju se različiti postupci u individualnom radu da bi im se pomoglo nadvladati osjećaj manje vrijednosti i da bi se donekle uspješno snalazili u obitelji, školi ili u odnosima s vršnjacima. Samim tim, ovakav pristup pravovremena interveniranja pokazao se veoma dostatnim za ovu skupinu ispitanika, što je vidljivo u vrlo visokim postotcima od 57 - 93\% uspješnosti, odnosno smanjenja simptoma koji idu u prilog razvoju poremećaja.

Kada se kod djeteta očituju eksternalizirani problemi povezani s problemima pažnje, ta su ponašanja najčešće u obliku opozicijskoga prkosna poremećaja. Prkos se može definirati i kao oblik pobune 
protiv autoriteta. Dijete se odupire odraslima na više načina: otvorenim neprihvaćanjem onoga što roditelj ili nastavnik traži, tvrdoglavošću kada uporno radi ono što mu je zabranjeno i pasivnošću, izbjegavajući zahtjeve odraslih. Istraživanjem su bila obuhvaćena četiri ispitanika s izraženim problemima iz ove skupine, čiji su pokazatelji napredovanja u procesu Programa prikazani u tablici 5.

Tablica 5. Uspješnost intervencija kod ispitanika s rizikom za razvoj eksternaliziranih problema povezanih s problemima pažnje

\begin{tabular}{|c|c|c|c|c|c|c|c|}
\hline \multirow[t]{6}{*}{ Statističke vrijednosti } & \multirow[t]{2}{*}{$\begin{array}{l}\text { Redni broj } \\
\text { ispitanika }\end{array}$} & \multirow{2}{*}{$\begin{array}{c}\begin{array}{c}\text { Ukupan } \\
\text { rezultat na I } \\
\text { samoiskazu }\end{array} \\
2\end{array}$} & \multirow{2}{*}{$\begin{array}{c}\begin{array}{c}\text { Ukupan } \\
\text { rezultat na II } \\
\text { samoiskazu }\end{array} \\
3\end{array}$} & \multirow{2}{*}{$\begin{array}{c}\begin{array}{c}\text { Ukupan } \\
\text { rezultat na III } \\
\text { samoiskazu }\end{array} \\
4\end{array}$} & \multicolumn{3}{|c|}{$\begin{array}{c}\text { Uspješnost intervencija izražena } \\
\text { postotcima }\end{array}$} \\
\hline & & & & & $5(3 / 2)$ & $6(4 / 3)$ & $7(4 / 2)$ \\
\hline & 1. & 62 & & 18 & & & $71,0 \%$ \\
\hline & 2. & 91 & 71 & 51 & $22,0 \%$ & $28,2 \%$ & $44,0 \%$ \\
\hline & 3. & 72 & 80 & 34 & $-11,1 \%$ & $57,5 \%$ & $52,8 \%$ \\
\hline & 4. & 82 & 36 & 8 & $56,1 \%$ & $77,8 \%$ & $90,2 \%$ \\
\hline Broj ispitanika & & 4 & 3 & 4 & & & \\
\hline Maksimum & & 91 & 80 & 51 & $100,0 \%$ & $77,8 \%$ & $90,2 \%$ \\
\hline Minimum & & 62 & 36 & 8 & $-11,1 \%$ & $28,2 \%$ & $44,0 \%$ \\
\hline
\end{tabular}

Tri ispitanika u riziku za razvoj eksternaliziranih problema povezanih s problemom pažnje testirani su u trima fazama procjene. Pokazatelji uspješnosti intervencija su u završnoj procjeni ove skupine ispitanika 44,0 - 90,2\%. Najveći pomak ostvaren je kod učenika pod rednim brojem 4., koji se pokazao sklonim za provođenje ovakve vrste pravovremene socijalnopedagoške intervencije.

Eksternalizirani, eksternalni ili uglavnom aktivni problemi u ponašanju odnose se, prema Bouillet i Uzelac (2007), na nedovoljno kontrolirana i na druga usmjerena ponašanja. U ta ponašanja mogu se ubrojiti: nametljivost, prkos, laganje, hiperaktivnost, neposlušnost, agresivnost i drugi. Velik broj studija upućuje na negativne ishode ranog izražavanja eksternaliziranih problema ponašanja jer su povezani s ozbiljnim problemima ponašanja u kasnijem uzrastu (Stormont, 2002., prema Herrera i Little, 2005) u obliku izražavanja asocijalnih ponašanja i zlouporabe psihoaktivnih supstancija u adolescenciji i u odrasloj dobi (Wesley i sur., 2012). S obzirom na to što navode, a i na činjenicu da je u uzorku ispitanika izdvojen najveći broj s eksternaliziranim problemima, važno je istaknuti potrebu adekvatna i pravovremena djelovanja u školi. Da je moguće pravovremeno i adekvatno djelovati strukturiranim socijalnopedagoškim metodama, govore u prilog rezultati nakon provedenih intervencija u tablici 6. 
Meliha Bijedić, Lejla Kuralić Čišić, Adela Jahić, Melisa Muminović Vildić: Samoprocjena...

Tablica 6. Uspješnost intervencija kod ispitanika s rizikom za razvoj eksternaliziranih problema

\begin{tabular}{|c|c|c|c|c|c|c|c|}
\hline \multirow{2}{*}{ Statističke vrijednosti } & $\begin{array}{c}\text { Redni broj } \\
\text { ispitanika }\end{array}$ & $\begin{array}{c}\text { Ukupan } \\
\text { rezultat na I } \\
\text { samoiskazu }\end{array}$ & $\begin{array}{c}\text { Ukupan } \\
\text { rezultat na II } \\
\text { samoiskazu }\end{array}$ & $\begin{array}{c}\text { Ukupan } \\
\text { rezultat na III } \\
\text { samoiskazu }\end{array}$ & \multicolumn{2}{|c|}{$\begin{array}{c}\text { Uspješnost intervencija izražena u } \\
\text { postotcima }\end{array}$} \\
\cline { 2 - 8 } & & 2 & 3 & 4 & $5(3 / 2)$ & $6(4 / 3)$ & $7(4 / 2)$ \\
\hline & 1. & 60 & & 20 & $100,0 \%$ & & $66,7 \%$ \\
\hline & 2. & 74 & 35 & 17 & $52,7 \%$ & $51,4 \%$ & $77,0 \%$ \\
\hline & 3. & 70 & & 26 & $100,0 \%$ & & $62,9 \%$ \\
\hline & 4. & 59 & & 0 & $100,0 \%$ & & $100,0 \%$ \\
\hline & 5. & 62 & & 18 & $100,0 \%$ & & $71,0 \%$ \\
\hline & 6. & 59 & & 32 & $100,0 \%$ & & $45,8 \%$ \\
\hline & 7. & 70 & & 0 & $100,0 \%$ & & $100,0 \%$ \\
\hline & 8. & 92 & 62 & 46 & $32,6 \%$ & $25,8 \%$ & $50,0 \%$ \\
\hline & 9. & 59 & & 16 & $100,0 \%$ & & $72,9 \%$ \\
\hline & 10. & 115 & & 67 & $100,0 \%$ & & $41,7 \%$ \\
\hline \multirow{2}{*}{ Broj ispitanika } & 11. & 58 & & 11 & $100,0 \%$ & & $81,0 \%$ \\
\hline Maksimum & & 11 & 2 & 11 & & & \\
\hline Minimum & & 58 & 35 & 0 & $32,6 \%$ & $25,8 \%$ & $41,7 \%$ \\
\hline
\end{tabular}

Iz tablice 6 uočljivo je da je od 11 ispitanika samo dvoje procijenjeno u trima fazama, a razlog tomu je naknadno otpočinjanje s intervencijama zbog naknadno dobivene roditeljske suglasnosti za uključivanje djeteta u intervencije. Rezultati dvaju ispitanika pokazuju izrazito visoku osjetljivost učenika na intervencije jer su na završnom samoiskazu pokazali potpuno odsustvo rizika za nastanak problema u ponašanju, dok se kod šest ispitanika bilježi uspješnost provedenih intervencija $66,00-81,0 \%$.

Općenito, intervencijama za rješavanje eksternaliziranih problema bilo je potrebno promijeniti stavove i ponašanje ispitanika, pomoći im da razviju socijalne vještine i vještine odolijevanja vršnjačkom pritisku.

Epidemiološke studije ističu da su internalizirani problemi, u prvom redu anksioznost i depresija, glavni javnozdravstveni problemi koji su prisutni kod 20\% djece u zajednici (Sawyer i sur., 2001). Ti emocionalni problemi rezultiraju patnjom mladih ljudi i obitelji jer relativno malo imaju stručnu pomoć. Istraživanja pokazuju da se u zemljama zapadne civilizacije kod približno $10 \%$ djece i mladih može govoriti o depresivnom poremećaju, 2 - 9\% djece pokazuje specifične fobije, a u 2 - 5\% djece nalazimo klinički značajne anksiozne simptome (Oatley, Jenkins, 2003).

Prediktor anksioznosti i depresije je povučenost. Obično se već u najranijoj životnoj dobi uočavaju djeca koja su „vođe”, lakše sklapaju prijateljstva, ekstrovertirana su i bučna, za razliku od one druge, manje uočljive i povučene ili introvertirane djece. Povučena djeca iznimno su sramežljiva, povučena, tiha, izbjegavaju kontakte s vršnjacima i s nepoznatim osobama bez obzira na dob. Uglavnom se druže i igraju s članovima obitelji ili dobro poznatim vršnjacima.

Situacije koje izazivaju povlačenje i anksioznost kod takve djece najčešće se manifestiraju pri izvođenju različitih aktivnosti pred drugima, poput čitanja naglas pred razrednim odjelom, pisanja na ploči, zajedničke igre... U takvim situacijama koriste se negativnim strategijama suočavanja putem kojih se mogu prepoznati: plakanje, tjelesne tegobe, zamuckivanja. Takva iskustva imaju negativne 
posljedice na samopoštovanje djece i njihova postignuća. Istraživanjem je bilo obuhvaćeno devet ispitanika koji izražavaju internalizirane probleme (tablica 7).

Tablica 7. Uspješnost intervencija kod ispitanika s rizikom za razvoj internaliziranih problemima

\begin{tabular}{|c|c|c|c|c|c|c|c|}
\hline \multirow[t]{2}{*}{ Statističke vrijednosti } & \multirow[t]{2}{*}{$\begin{array}{l}\text { Redni broj } \\
\text { ispitanika }\end{array}$} & \multirow{2}{*}{$\begin{array}{c}\begin{array}{c}\text { Ukupan } \\
\text { rezultat na I } \\
\text { samoiskazu }\end{array} \\
2\end{array}$} & \multirow{2}{*}{$\begin{array}{c}\begin{array}{c}\text { Ukupan } \\
\text { rezultat na II } \\
\text { samoiskazu }\end{array} \\
3\end{array}$} & \multirow{2}{*}{$\begin{array}{c}\begin{array}{c}\text { Ukupan } \\
\text { rezultat na III } \\
\text { samoiskazu }\end{array} \\
4\end{array}$} & \multicolumn{3}{|c|}{$\begin{array}{c}\text { Uspješnost intervencija izražena } \\
\text { postotcima }\end{array}$} \\
\hline & & & & & $5(3 / 2)$ & $6(4 / 3)$ & $7(4 / 2)$ \\
\hline & 1. & 85 & 20 & 6 & $76,5 \%$ & $70,0 \%$ & $92,9 \%$ \\
\hline & 2. & 68 & & 26 & $100,0 \%$ & & $61,8 \%$ \\
\hline & 3. & 49 & & 0 & $100,0 \%$ & & $100,0 \%$ \\
\hline & 4. & 90 & 62 & 41 & $31,1 \%$ & $33,9 \%$ & $54,4 \%$ \\
\hline & 5. & 72 & 52 & 28 & $27,8 \%$ & $46,2 \%$ & $61,1 \%$ \\
\hline & 6. & 67 & 28 & 42 & $58,2 \%$ & $-50,0 \%$ & $37,3 \%$ \\
\hline & 7. & 96 & & 58 & $100,0 \%$ & & $39,6 \%$ \\
\hline & 8. & 77 & 57 & 32 & $26,0 \%$ & $43,9 \%$ & $58,4 \%$ \\
\hline & 9. & 85 & & 49 & $100,0 \%$ & & $42,4 \%$ \\
\hline Broj ispitanika & & 9 & 5 & 9 & & & \\
\hline Maksimum & & 96 & 62 & 58 & $100,0 \%$ & $70,0 \%$ & $100,0 \%$ \\
\hline Minimum & & 49 & 20 & 0 & $26,0 \%$ & $-50,0 \%$ & $37,3 \%$ \\
\hline
\end{tabular}

Kod svih ispitanika iz skupine internaliziranih problema došlo je do pozitivnih pomaka u ponašanju u završnoj procjeni u odnosu na inicijalnu, značajni su visoki postotci u smanjenju skora negativnih simptoma. $U$ ispitanika pod rednim brojem 3. došlo je do potpuna izostanka simptoma koji bi ukazivali na razvoj problema u ponašanju.

Intervencije kod ove skupine ispitanika bile su temeljene na učenju prema modelu, stjecanju pozitivnih iskustava i učenju socijalnih vještina. Kognitivno-bihevioralni pristup prilikom interveniranja podrazumijevao je kombiniranje vještine nošenja s nepoželjnim uzbuđenjem koje se javlja u situaciji koju obilježava emocija straha i ponašanje koje opisujemo kao socijalnu povučenost. Ispitanici su najprije učili o svojim nepoželjnim emocionalnim, kognitivnim i ponašajnim reakcijama, a nakon toga svladavali su strategije nošenja s uzbuđenjem. Edukacijska komponenta tretmana pomogla je učenicima identificirati njihove anksiozno uzbuđujuće misli te su podučeni relaksirajućim odgovorima i osiguravanju strategije za moderiranje anksioznog uzbuđenja. S obzirom na to da se problem kod ove djece uglavnom temelji na zabrinutosti oko toga što drugi misle o njima, kognitivni pristup prilikom interveniranja pokazao se naročito efikasnim. On je uključivao kognitivno restrukturiranje, tj. mijenjanje negativna načina razmišljanja, ali i stjecanje iskustva koje će u povoljnom smjeru promijeniti djetetove negativne sheme.

\section{Ograničenja istraživanja}

Jedno od istraživačkih ograničenja svakako je broj ispitanika, a što je bilo uvjetovano pristankom roditelja za uključivanje učenika u intervencije. Ako roditelji nisu dali pismeni pristanak, nije bilo moguće provoditi intervencije te takve učenike uključiti u istraživanje bez obzira na visoke rezultate dobivene samoprocjenom učenikova ponašanja. Pojedini roditelji naknadno su davali pristanak i tražili uključivanje djeteta, što nije jamčilo očekivane rezultate u funkcioniranju i ponašanju djeteta jer učenik nije bio obuhvaćen svim planiranim aktivnostima. Jedno od ograničenja u radu je 
nepostojanje kontrolne skupine ispitanika. S obzirom na to da se procjena radila samo iz jednog izvora, mjerni instrument svakako može biti ograničavajući čimbenik, ispitanici su znali da ih se ispituje, što je donekle moglo proizvesti i umjetne rezultate te se prilikom interveniranja dolazilo do drugih pokazatelja. Budući da se radi o samoprocjeni, djeca, posebice starija, mogla su pozitivnije opisati svoje ponašanje i reakcije nego što je to uistinu točno. $U$ budućim istraživanjima prijeko je potrebno jasno povezati specifičnosti procjene i intervencije te tako osigurati sve elemente programa utemeljenih na dokazima.

\section{Zaključak}

Rizici za pozitivan rast i razvoj djece i mladih posljednjih su nekoliko desetljeća čini se veći nego ikada; njihovi razmjeri, nažalost, još nisu u dovoljnoj mjeri ni ispitani ni prezentirani na adekvatan način stručnoj i drugoj javnosti. U Bosni i Hercegovini ne postoje odgovarajući programi ranog interveniranja na rizična ponašanja i poremećaje u ponašanju djece i mladih čija je učinkovitost utemeljena na znanstvenim dokazima.

Provedene socijalnopedagoške intervencije obuhvatile su školski kontekst života djece u riziku za nastanak problema u ponašanju. U rezultatima je prikazana uspješnost intervencija kod ispitanika s rizikom za razvoj kombiniranih internaliziranih i eksternaliziranih problema, internaliziranih problema, internaliziranih problema i problema pažnje, eksternaliziranih problema i problema pažnje i eksternaliziranih problema. Kod svih ispitanika došlo je do pozitivnih promjena u ponašanju u završnom samoiskazu. Kod svih ispitanika s kombiniranim internaliziranim i eksternaliziranim problemima u ponašanju došlo je do pozitivnih rezultata na završnom testiranju s pokazateljima uspješnosti do $63 \%$. Kada je u pitanju skupina ispitanika s internaliziranim problemima i s problemima pažnje, socijalnopedagoške intervencije iznimno su prikladne za ispitanike s ovom skupinom problema, $s$ pokazateljima uspješnosti do $87,3 \%$. U skupini ispitanika s problemima pažnje pokazatelji uspješnosti intervencija u završnoj procjeni ove skupine ispitanika kreću se 50,0-90,0\%. Intervencijski pristupi, koji se koriste kod djece s problemima pažnje, u kojih se još nisu razvili pravi simptomi, pedagoško-edukacijski i bihevioralno-kognitivni su, da bi se kontrolirali simptomi i ublažili specifični djetetovi problemi. Tri ispitanika u riziku za razvoj eksternaliziranih problema povezanih s problemom pažnje testirani su u trima fazama procjene. Pokazatelji uspješnosti intervencija u završnoj procjeni ove skupine ispitanika iznose 44,0 - 90,2\% s obzirom na to da rezultati kod dvaju ispitanika pokazuju izrazito visoku otvorenost učenika za intervencije jer su na završnom samoiskazu imali potpuno odsustvo rizika za nastanak problema u ponašanju, dok se kod šest ispitanika bilježi uspješnost provedenih intervencija 66,00 - 81,0\%. Općenito, intervencije za rješavanje eksternaliziranih problema usmjerene su na promjenu stavova i ponašanja mladih te pružanje pomoći da razviju socijalne vještine i vještine odolijevanja vršnjačkom pritisku. Kod svih ispitanika iz skupine internaliziranih problema došlo je do pozitivnih pomaka u ponašanju u završnoj procjeni u odnosu na inicijalnu, primjetni su visoki postotci u smanjenju skora negativnih simptoma. Intervencije kod ove skupine ispitanika bile su temeljene na učenju prema modelu, stjecanju pozitivnih iskustava i učenju socijalnih vještina. Dobivenim pozitivnim rezultatima na završnoj samoprocjeni kod svih ispitanika može se zaključiti da je postavljena hipoteza potvrđena. Rad pridonosi procesu razvoja učinkovite socijalnopedagoške prakse. 


\section{Literatura}

Abu-Rayya, H.M., Yang, B. (2012). Emotional and Behavioral Problems and Their Underlying Risk Factors Among Children in New South Wales. International Journal of Mental Health, 41(3), 3-23.

Achenbach, T. M., Rescorla, L. A. (2001). The manual for the ASEBA school-age forms profiles. Burlington, VT, University of Vermont, Research Center for Children, Youth, and Families.

Achenbach, T. M., Dumenci, L., Rescorla, L. A. (2003). DSM-oriented and empirically based approaches to constructing scales from the same item pools. Journal of Clinical Child and Adolescent Psychology, 32, 328-340.

Barkley RA, Fischer M, Smallish L, Fletcher K. (2002). The persistence of attention-deficit/hyperactivity disorder into young adulthood as a function of reporting source and definition of disorder. J Abnorm Psychol, 111, 279-289.

Bouillet, D. (2015). Konceptualni okvir razvoja modela rane odgojno-obrazovne intervencije. U: Bouillet, D. (ur.): Razvoj modela rane odgojno-obrazovne intervencije u osnovnoj školi: od ideje do evaluacije ( str. 25-47). Zagreb: Forum za slobodu odgoja.

Bouillet, D. (2016). Procjena potreba učenika osnovne škole u svrhu planiranja socijalnopedagoških intervencija - standardizacija mjernog instrumenta. Kriminologija i socijalna integracija, 24(2), 93-114.

Bouillet, D., Uzelac, S. (2007). Osnove socijalne pedagogije. Zagreb: Školska knjiga.

Bouillet, D., Bićanić, J., Ivančan, A., Novosel Guszak, D., Rovis Brandić, A., Sitar, M. (2018). Socijalnopedagoški mozaik: Razvoj modela potpore učenicima s problemima u ponašanju. Zagreb: Školska knjiga.

Conley, L., Marchant, M., Caldarella, P. (2014). A comparison of teacher perceptions and research-based categories of student behavior difficulties. Education, 134(4), 439-450.

Gadow, K. D., Nolan, E. E., Litcher, L., Carlson, G. A., Panina, N., Golovakha, E., .., Bromet, E. J. (2000). Comparison of attention-deficit/hyperactivity disorder symptom subtypes in Ukrainian schoolchildren. Journal of the American Academy of Child \& Adolescent Psychiatry, 39(12), 1520-1527.

Herrera, M., Little, E. (2005). Behaviour Problems Across Home and Kindergarten in an Australian Sample. Australian Journal of Educational \& Developmental Psychology, 5, 77-90.

Jackson, Y. (2005). Testing the compensatory and immunity models of children's adaptive behaviors: The role of appraisal. American Journal of Orthopsychiatry, 75 (3), 369-380.

Koller-Trbović, N., Mirosavljević, A., Jeđud Borić, I. (2013). Procjena intervencijskih potreba djece i mladih s problemima u ponašanju. U: Žižak, A., Koller-Trbović, N. (ur.): Procjena rizika i snaga u funkciji planiranja tretmana: Rezultati znanstvenog projekta: Usklađivanje intervencija s potrebama djece i mladih u riziku: izrada modela (str. 23-66). Zagreb: Edukacijsko-rehabilitacijski fakultet Sveučilišta u Zagrebu.

Kuralić-Čišić, L. (2013). Povezanost karakteristika porodice i poremećaja u ponašanju u adolescenciji. Doktorska disertacija, Univerzitet u Tuzli. Edukacijsko-rehabilitacijski fakultet.

Liabo K., Richardson J. (2007). Conduct disorder and offending behaviour in young people. Child and adolescent mental heath series. Philadelphia: Jessica Kingsley Publishers.

Oatley, K., Jenkins, J. M. (2003). Razumijevanje emocija. Jastrebarsko: Naklada Slap 
Meliha Bijedić, Lejla Kuralić Čišić, Adela Jahić, Melisa Muminović Vildić: Samoprocjena...

Pastor, P.N., Reuber, C.A, Duran, C.R. (2012). Identifying Emotional and Behavioral Problem in Children Aged 4-17 Years. National Health Statistics Reports. No. 48. National Center for Health Statistics, United States.

Pavin Ivanec, T. (2015). Potrebe učenika za ranom odgojno-obrazovnom intervencijom: fenomenologija i rasprostranjenost problema u ponašanju. U: Bouillet, D. (ur.): Razvoj modela rane odgojno-obrazovne intervencije u osnovnoj školi: od ideje do evaluacije (33-47). Zagreb, Forum za slobodu odgoja.

Sawyer, M. G., Arney, F. M., Baghurst, P. A., Clark, J. J., Graetz, R.J., Kosky, R.J. (2001). The mental health of young people in Australia: Key findings from the child and adolescent component of the national survey of mental health and well-being. Australian and New Zealand Journal of Psychiatry, 35, 806-814.

Žižak, A. (2010). Teorïske osnove intervencija. Zagreb: Edukacijsko-rehabilitacijski fakultet Sveučilišta u Zagrebu.

Žunić-Pavlović V., Kovačević-Lepojević, (2010). Prevencija i tretman poremećaja u ponašanju. Univerzitet u Beogradu: Fakultet za specijalnu edukaciju i rehabilitaciju.

Wesley, C.T., Tomek, S., Bolland, K.A.; Hooper, L.M., Jaggers, J., Bolland, J.M. (2012). A longitudinal examination of predictors of delinquency: Analysis of data from the Mobile Youth Survey. Children \& Youth Services Review, 34(12), 2400-2408. 
Meliha Bijedić

Associate Professor at the Department of Behavioral Disorders Faculty of Education and Rehabilitation Sciences, University of Tuzla

Lejla Kuralić Čišić

Assistant Professor at the Department of Behavioral Disorders Faculty of Education and Rehabilitation Sciences, University of Tuzla

Adela Jahić

Senior Research and Teaching Assistant at the Department of Behavioral

Disorders

Faculty of Education and Rehabilitation Sciences, University of Tuzla

Melisa Muminović Vildić

Research and Teaching Assistant at the Department of Behavioral Disorders

Faculty of Education and Rehabilitation Sciences, University of Tuzla

\title{
Self-Assessment of Behavioral Behavior of Primary School Students After Participating in Social-Pedagogical Interventions
}

\begin{abstract}
The aim of the paper is to present the results of the Social Pedagogical Intervention Program for students at risk of developing behavioral problems. The program was implemented in three primary schools in the area of Tuzla in Bosnia and Herzegovina during the 2016/2017 school year. An estimate was made for 500 students (248 boys and 252 girls) aged 1015, of which 86 pupils ( 39 boys and 47 girls) were estimated to be at risk for developing behavioral problems. Achenbach's Dimensional Behavioral Behavioral Classification (Achenbach, Rescorla, 2001) was used for evaluation. In order to determine the effects of the Program, students' testing was performed in the initial, median and final stages. Structured pedagogical procedures implemented within groups and on individual basis changed students' behaviors towards socially desirable models. Group and individual meetings with students were carried out for two hours a week. In addition, the program also involved teachers and parents who attended special workshops. Descriptive statistical methods in Youth Self Report scales were used to show changes in students with externalized and internalized problems. The program confirms the expectation that timely identification of the students at risk of behavioral problems and timely and adequate social-pedagogical intervention in working with children and their parents will result in positive changes in behavior.
\end{abstract}

Keywords: behavioral problems, elementary school students, self-assessment, social-pedagogical intervention. 